Check for updates

Cite this: RSC Adv., 2021, 11, 35174

\title{
Polyfluoroalkylated antipyrines in Pd-catalyzed transformations $\uparrow$
}

\author{
Evgeny V. Shchegolkov, (D) ${ }^{a}$ Yanina V. Burgart, (DD a Daria A. Matsneva, ${ }^{a}$

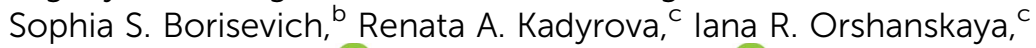 \\ Vladimir V. Zarubaev (D) ${ }^{c}$ and Victor I. Saloutin (D)*a
}

In the direct $\mathrm{C}-\mathrm{H}$ arylation with arylhalogenides in the presence of $\mathrm{Pd}(\mathrm{OAc})_{2}$, trifluoromethyl-containing antipyrine reacts very slowly and incompletely owing to the low nucleophilicity of its C4 center. However, it was effective in modifying polyfluoroalkyl-substituted 4-bromo- and 4-iodo antipyrines by the Suzuki and Sonogashira reactions. It was established that using $\operatorname{Pd}_{2}(\mathrm{dba})_{3}$ as catalyst and XPhos as phosphine ligand was the optimal catalytic system for the synthesis of 4-aryl- and 4-phenylethynyl-3polyfluoroalkyl-antipyrines. Moreover, iodo-derivatives as the initial reagents were found to be more advantageous compared to bromo-containing analogs. It was found that 4-phenylethynyl-5- $\mathrm{CF}_{3}-$ antipyrine has a moderate activity against the influenza virus A/Puerto Rico/8/34 (H1N1) and 4-iodo-5$\mathrm{CF}_{3}$-antipyrine reveals a weak activity against the vaccine virus (strain Copenhagen) and bovine diarrhea virus (strain VC-1).

Received 17th September 2021 Accepted 21st October 2021

DOI: $10.1039 / \mathrm{d} 1 \mathrm{ra06967e}$

rsc.li/rsc-advances

sclerosis, aminophenazone (3) with antipyretic and antiinflammatory activity, eltrombopag (4) for the treatment of low blood platelet counts, dichloralphenazone (5) for relieving tension and vascular headaches, metamizole (6) to stop severe pain and fever, sulfamazone (7) - sulfanilamide antibiotic with antipyretic properties, and analgesics propyphenazone (8) and nifenazone (9) (please see, DrugBank).

Note that fluorine-containing pyrazolone derivatives are promising because of their potential use in the pharmaceutical

\section{(ear drops). ${ }^{13}$}

Research in recent years has shown that the pyrazolone core is a universal structure ${ }^{\mathbf{1 4}}$ to develop substances with various types of biological action including antimicrobial, ${ }^{11}$ antitubercular, ${ }^{15,16}$ antiviral, ${ }^{17}$ anticancer, ${ }^{18-21}$ analgesic, ${ }^{22}$ anti-inflammatory, ${ }^{23}$ antioxidant, ${ }^{24}$ and anti-diabetic ${ }^{25}$ activities as well as action on $\mathrm{CNS},{ }^{26,27}$ etc.

The several drugs containing pyrazolone scaffold is presently approved for medical use (Fig. 1). These are edaravone (2) with antiradical properties for the treatment of amyotrophic lateral

${ }^{a}$ Postovsky Institute of Organic Synthesis, Ural Branch of the Russian Academy of Sciences, S. Kovalevskoi St., 22, Ekaterinburg 620990, Russia.E-mail: saloutin@ios. uran.ru

${ }^{b}$ Ufa Institute of Chemistry, Russian Academy of Sciences, 71 October Ave., Ufa, 450054, Russia

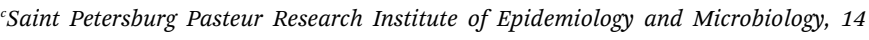
Mira St., Saint-Petersburg, 197101, Russia

$\dagger$ Electronic supplementary information (ESI) available: Detailed experimental procedures, Tables S1-S5, copies of NMR spectra. CCDC 2110385. For ESI and crystallographic data in CIF or other electronic format see DOI: 10.1039/d1ra06967e
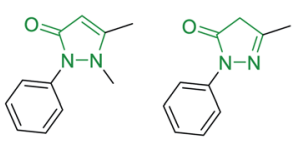

Antipyrine (1) Edaravone (2)

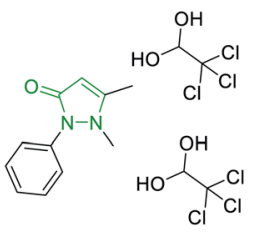

Dichloralphenazone (5)

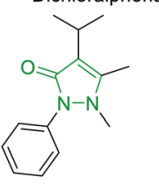

Propyphenazone (8)

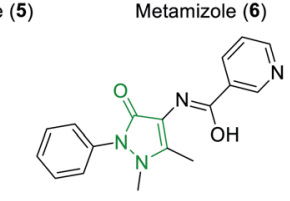

Nifenazone (9)
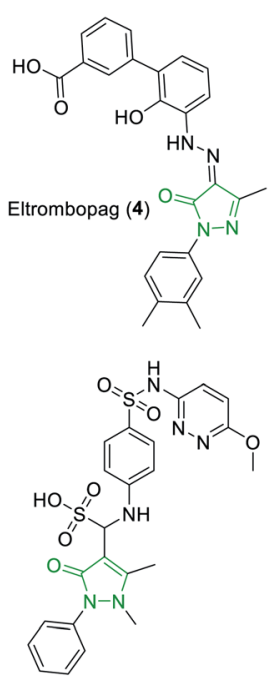

Sulfamazone (7)

Fig. 1 Drugs based on pyrazolone core. 
industry. ${ }^{28-33}$ For example, the medicines containing trifluoromethyl-pyrazole cycle are celecoxib, ${ }^{34}$ mavacoxib ${ }^{35}$ (COX-2 selective inhibitors), and razaxaban ${ }^{36}$ (inhibitor of coagulation blood factor Xa).

Recently, we have developed the methods for synthesis of polyfluoroalkyl-containing antipyrines. ${ }^{37} \quad \mathrm{CF}_{3}$-antipyrine (1methyl-2-phenyl-5-trifluoromethyl-1,2-dihydro-3H-pyrazolon-3one) was found to show an anti-inflammatory and analgesic activity at the level of diclofenac and metamizole or significantly higher, and its antipyretic effect was higher than that of paracetamol. ${ }^{38}$ Therefore, the promising challenge is the development of methods for functionalization of polyfluoroalkylantipyrines.

The modification of organic compounds via the generation of new carbon-carbon bond is known to be one of the most used approaches to generate new molecules. In the midseventies of the 20th century, a wide range of $\mathrm{C}-\mathrm{C}$ bond formation reactions catalyzed by metal complexes was discovered, which made it possible to put these transformations in a row of the most effective and successful tools of organic synthesis. The great research interest in these transformations is caused primarily by their synthetic capabilities, which allow a wide range of organic substrates to be involved in the reactions, as well as by high selectivity in the formation of target products and by the comparatively low requirements to purity of the reagents. ${ }^{39,40}$

The cross-coupling reactions allow $\mathrm{C}-\mathrm{C}$ bonds not only to be generated between aryl components but also to involve various hetaryl fragments in the process, which significantly extends their synthetic potential to modify the natural substances and pharmacologically active compounds. ${ }^{41,42}$ Recently, the methods have been enthusiastically investigated for modifying pyrazoles, including polyfluoroalkyl-containing ones, at the position 4. For example, the Suzuki cross-coupling reaction of 3chloro-4-iodo-1-methyl-5-(trifluoromethyl)-1 $\mathrm{H}$-pyrazole with phenylboronic acid in the presence of $\mathrm{Pd}\left(\mathrm{PPh}_{3}\right)_{4}$ led to 3-chloro1-methyl-4-phenyl-5-(trifluoromethyl)-1H-pyrazole. ${ }^{43}$ We used an analogous catalyst to modify 4-bromo-1,5-diphenyl-3-(polyfluoroalkyl)- $1 H$-pyrazoles in the conditions of microwave irradiation to obtain 4 -(het)aryl-substituted pyrazoles. ${ }^{44}$ The 4 -iododerivatives of a celecoxib and its analogs were used in the crosscoupling reactions with copper(I) cyanide to give 4-cyano-3- $\mathrm{CF}_{3}$ pyrazoles, with phenylboronic acid in the presence of $\mathrm{Pd}\left(\mathrm{PPh}_{3}\right)_{4}$ and $\mathrm{K}_{2} \mathrm{CO}_{3}$ - triaryl-substituted $3-\mathrm{CF}_{3}$-pyrazoles, with 4methoxythiophenol in the presence of the catalytic system of $\mathrm{Pd}(\mathrm{dba})_{2}$-Xantphos - 4-arylthio-3- $\mathrm{CF}_{3}$-pyrazoles, and in the conditions of Sonogashira reaction - 4-phenylethynyl-3- $\mathrm{CF}_{3}$ pyrazoles in. ${ }^{45}$

A great research attention has also been paid to the modification of antipyrine and its analogs in the cross-coupling reactions. A convenient and ligand-free method has been described for the synthesis of a series of 4-aryl-antipyrines based on 4unsubstituted derivatives and arylhalogenides via an activation of $\mathrm{C}-\mathrm{H}$ bond by palladium(II) acetate in the presence of $\mathrm{Ag}_{2} \mathrm{CO}_{3} \cdot{ }^{46}$ Reactivity of para-, meta- and ortho-substituted arylbromides has been investigated in the reaction with antipyrine by $\mathrm{Pd}(\mathrm{OAc})_{2}$ and $\mathrm{K}_{2} \mathrm{CO}_{3} \cdot{ }^{47} \mathrm{~A}$ method has been suggested for the direct introduction of arylthiol and arylselenium residues into antipyrines by di- $p$-tolyldisulfide or diphenyldiselenide using catalyst system AgOTf/AgOAc. ${ }^{48}$ An effective way of carrying out the cross-coupling reaction of 4-iodo-antipyrine with arylboronic acids has been found on $\mathrm{Pd} /$ nanoglobular carbon support. ${ }^{49}$ The reactions have been described for Sonogashira cross-coupling of antipyrine with electrophile alkynylation reagent - 1-[(triisopropylsilyl)ethynyl]-1,2-benziodoxol-3(1H)one (TIPS-EBX). ${ }^{\mathbf{5 0}}$

In this report, we investigated and compared the capabilities of polyfluoroalkyl-containing antipyrines in Pd-catalyzed $\mathrm{C}-\mathrm{H}$ arylations and Suzuki and Sonogashira cross-coupling reactions, and studied antiviral activity of the synthesized compounds.

\section{Results and discussion}

The literature data analysis has shown that antipyrine and its non-fluorinated analogs readily undergo the Pd-catalyzed direct arylation with the different arylhalogenides. ${ }^{\mathbf{4 6 , 4 7}}$ However, our numerous efforts to involve 5-trifluoromethyl-antipyrine 1a into the direct arylation with arylhalogenides were ineffective, despite the use of various palladium catalysts $\left\{\mathrm{Pd}(\mathrm{OAc})_{2}\right.$, $\left.\mathrm{Pd}_{2}(\mathrm{dba})_{3}\right\}$, bases (AcOK, $\mathrm{K}_{2} \mathrm{CO}_{3}, \mathrm{Cs}_{2} \mathrm{CO}_{3}, \mathrm{~K}_{3} \mathrm{PO}_{4}$ ), ligands (ligand-free, XPhos), solvents $\left(\mathrm{CO}(\mathrm{OEt})_{2}, \mathrm{EtOH}-\mathrm{H}_{2} \mathrm{O}\right.$, DMA, toluene, 1,4-dioxane), temperature modes (100-160 $\left.{ }^{\circ} \mathrm{C}\right)$ and ratios of reagents in these reactions. The extended experiments are presented in Table S1 (please see, ESI $\dagger$ ).

The attempts to introduce phenyl iodide $2 \mathbf{a}$ and 3-cyanophenylbromide $\mathbf{2 b}$ in the reaction with $\mathrm{CF}_{3}$-antipyrine $\mathbf{1 a}$ (entry 1-4, Table $\mathrm{S} 1 \dagger$ ) may be recognized as practically unsuccessful, since the content of the expected 4-aryl-antipyrines $\mathbf{3 a}, \mathbf{b}$ in accordance with GLC-mass spectrometry was only 5 and $12 \%$, respectively. The conversion of $\mathrm{CF}_{3}$-antipyrine $1 \mathrm{a}$ in the reaction with 4-cyanophenyl halides $2 \mathbf{b}, \mathbf{c}$ and with 4-nitrophenyl iodide 2e into the corresponding products $3 \mathbf{c}-\mathbf{d}$ was no more than $21 \%$ (entries 5-23, Table S1 $\dagger$ ). However, the use of aryl bromides $\mathbf{2 f}, \mathbf{h}, \mathbf{i}$ in the reaction with antipyrine $\mathbf{1 a}$ led to the higher content of the target products $\mathbf{3 d - f}$ in a reaction mixture in the range of $32-42 \%$ (entries 24, 26 and 27 , Table S1†). We were successful in isolating the substances $\mathbf{3 d - f}$ in a pure form and the compound $\mathbf{3 c}$ in a mixture with the initial antipyrine $1 \mathrm{a}$ (the $3 c: 1 a$ ratio was $83: 17$ ) (Scheme 1).

The analysis of all the reaction conditions showed that the catalyst $\mathrm{Pd}(\mathrm{OAc})_{2}$ was more effective than $\mathrm{Pd}_{2}(\mathrm{dba})_{3}$ in the direct arylation, and using the base $\mathrm{K}_{3} \mathrm{PO}_{4}$ was more successful. Among all the solvents, the definitely best one was eco-friendly $\mathrm{CO}(\mathrm{OEt})_{2}$ (ref. 51-54) at $150-160{ }^{\circ} \mathrm{C}$. In addition, all transformations did not require a phosphonium ligand to be used. Using aryl bromides was found to be more effective than aryl iodide.

Apparently, in the reactions with electrophile reagents compared to non-fluorinated analogs, the reduced reactivity of 5-trifluoromethyl-antipyrine 1a was assumed to be caused by the deactivation of carbon $\mathrm{C} 4$ due to the influence of the neighboring electron-withdrawing fluorinated substituent. To explain this assumption, we evaluated the Fukui dual 


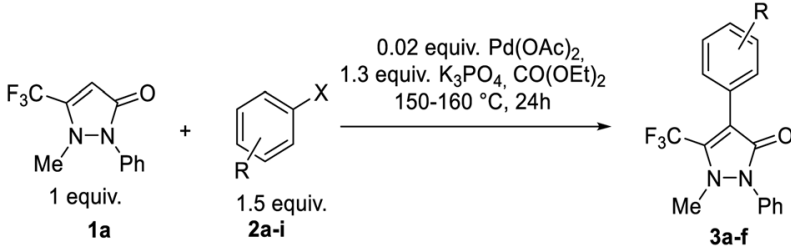

2: $\mathrm{R}=\mathrm{H}, \mathrm{X}=\mathrm{I}(\mathrm{a}) ; \mathrm{R}=3-\mathrm{CN}, \mathrm{X}=\mathrm{Br}(\mathbf{b}) ; \mathrm{R}=4-\mathrm{CN}, \mathrm{X}=\mathrm{I}$ (c), $\mathrm{Br}$ (d); $\mathrm{R}=4-\mathrm{NO}_{2}, \mathrm{X}=\mathrm{I}(\mathrm{e}), \mathrm{Br}(\mathbf{f}) ; \mathrm{R}=4-\mathrm{CF}_{3}, \mathrm{X}=\mathrm{I}(\mathbf{g}), \mathrm{Br}(\mathbf{h}) ; \mathrm{R}=3-\mathrm{CF}_{3}, \mathrm{X}=\mathrm{Br}(\mathbf{i})$.<smiles></smiles><smiles>Cn1[nH]c(=O)c(-c2cccc(C#N)c2)c1C(F)(F)F</smiles>

$3 a, 0(5) \%$ *<smiles>O=C1C(=O)N(c2ccccc2)C(C(F)(F)F)=C1c1ccc([N+](=O)[O-])cc1</smiles>

3d, $27(42) \%$
$3 \mathbf{b}, 0(12) \%$<smiles>Cn1c(-c2ccc(C(F)(F)F)cc2)c(-c2ccccc2)c(=O)n1-c1ccccc1</smiles>

$3 e, 25(40) \%$
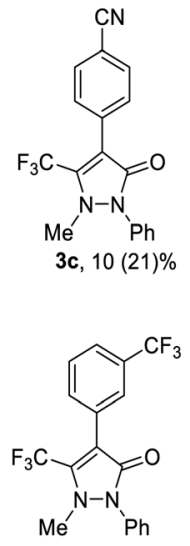

3f, $23(32) \%$ *preparative yield (conversion according to GC/MS)

Scheme 1 Direct $\mathrm{C}-\mathrm{H}$ arylation of antipyrine $1 \mathrm{a}$.

descriptors for centers $\mathrm{C} 4$ of antipyrine (Ant) and $\mathrm{CF}_{3}$-antipyrine 1a (Fig. 2) using quantum-chemical calculations.

According to previous report, ${ }^{55}$ the dual descriptor is able to unambiguously expose truly nucleophilic and electrophilic regions on a molecule. The reaction center $\mathrm{C}_{4}$ of $\mathrm{CF}_{3}$-antipyrine 1a was found to be characterized with more positive values of the dual descriptor of Fukui function $\Delta f$, which points to its higher electrophilicity in comparison with the same center of Ant. ${ }^{56}$ It explains the weak reactivity of compound $1 \mathrm{a}$ in the reactions of electrophile arylation comparing to the nonfluorinated antipyrine in analogous transformations. ${ }^{46,47}$
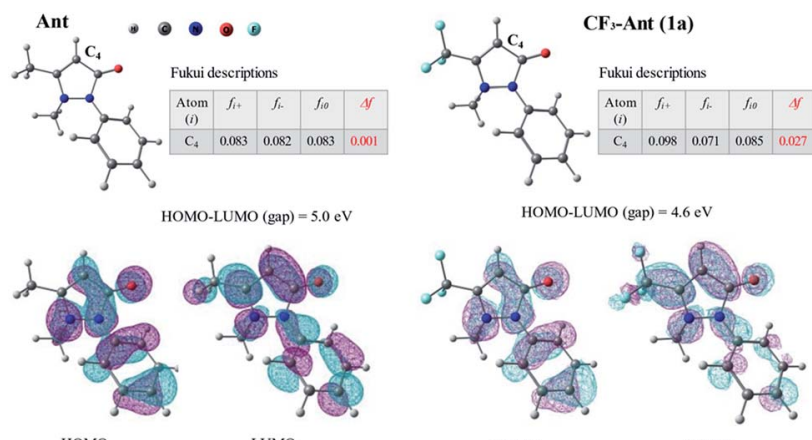

номо

LUMO

номо

LUMO

Fig. 2 The dual descriptor of Fukui functions for antipyrine (Ant) and $\mathrm{CF}_{3}$-antipyrine 1a, HOMO-LUMO gap and visualization.
Then, we investigated the possibility of modifying polyfluoroalkyl-antipyrines $\mathbf{1}$ at the center $\mathrm{C} 4$ in the Pdcatalyzed Suzuki and Sonogashira cross-coupling reactions. At first, 4-bromo-5-polyfluoroalkyl-antipyrines 4a-d and 4-iodo-5polyfluoroalkyl-antipyrines $\mathbf{5 a}, \mathbf{b}$ were synthesized by the treatment of the initial heterocycles 1a-d with $\mathrm{N}$-bromo- or $\mathrm{N}$-iodosuccinimide (NXS) (Scheme 2).

The reactions were running readily at room temperature with the good yields. The structure of the obtained halogencontaining antipyrines $\mathbf{4 a - d}$ and $\mathbf{5 a}$, b was confirmed by IR and NMR spectroscopy and the elemental analysis. The halogenation reaction is confirmed by the absence of the singlet signal of $=\mathrm{CH}$ proton at $\delta \sim 5-6 \mathrm{ppm}$ in ${ }^{1} \mathrm{H}$ NMR spectra of the compounds $\mathbf{4 a - d}$ and $\mathbf{5 a}, \mathbf{b}$.

Further, we studied the Suzuki reaction of halogensubstituted antipyrines $\mathbf{4 a - d}$ and $\mathbf{5 a}, \mathbf{b}$. To search for optimal conditions, we chose the synthesis of 4-phenyl-5trifluoromethyl-antipyrine 3a via cross-coupling reaction of 1 equiv. of 4-bromo-5-trifluoromethyl-antipyrine 4a with 1.2 equiv. of phenylboronic acid in the presence of 2.5 equiv. of base $\mathrm{K}_{2} \mathrm{CO}_{3}$, varying the solvent, palladium catalyst, and phosphine ligand. The reactions were performed at $100{ }^{\circ} \mathrm{C}$ in the closed vials under inert gas. A ratio of the reaction products was determined by GLC-mass spectrometry. The data on selecting the reaction conditions are given in Table S2. $\dagger$

Initially, a mixture of THF- $\mathrm{H}_{2} \mathrm{O}(3: 4)$ was applied as solvent, and $\mathrm{Pd}\left(\mathrm{PPh}_{3}\right)_{4}$ as catalyst/ligand system. There was a partial conversion of the initial bromo-antipyrine $4 \mathbf{a}$ under these conditions (entry 1, Table S2 $\dagger$ ). The replacement of THF by aqueous ethanol led to full conversion of the initial heterocycle 4a, but the reaction was accompanied by debromination of bromo-antipyrine 4a into the parent antipyrine 1a and the byproducts formation (entry 2, Table S2 $\dagger$ ).

With aqueous ethanol chosen as a solvent, we investigated the possibility to apply $\operatorname{Pd}_{2}(\mathrm{dba})_{3}$ as a catalyst in combination with various phosphine ligands: $\mathrm{P}(o-\mathrm{Tol})_{3}, \mathrm{P}(p-\mathrm{Tol})_{3}$, XPhos - 2-

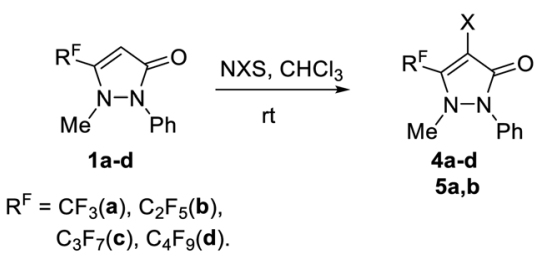
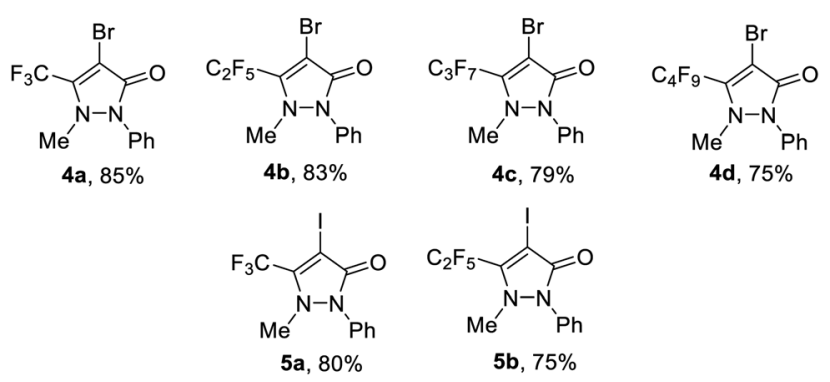

Scheme 2 Synthesis of 4-bromo-antipyrines $4 a-d$ and 4-iodo-antipyrines $5 a, b$. 
dicyclohexylphosphino-2' ${ }^{\prime} 4^{\prime}, 6^{\prime}$-triisopropylbiphenyl, Xantphos - 4,5-bis(diphenylphosphino)-9,9-dimethylxanthene and BINAP - ( \pm )-2,2'-bis(diphenylphosphino)-1,1'-binaphthalene, [1,1'Binaphthalene]-2,2'-diylbis[diphenylphosphine]. It was found that in all the cases the reaction proceeded with almost complete conversion of the starting bromo-antipyrine $4 \mathbf{4 a}$ (entries 3-7, Table S2†).

However, the catalyst system $\operatorname{Pd}_{2}(\mathrm{dba})_{3} /$ XPhos (entry 5, Table $\mathrm{S} 2 \dagger)$ was found to be the most effective. In these conditions the content of targeted compound 4a reached $86 \%$, and the contents of debromination product and impurities were $6 \%$ and $8 \%$, respectively. Note that the reaction in the same catalyst system under the microwave irradiation (entry 8 , Table S2 $\uparrow$ ) led to the formation of a large number of by-products, and as a result the product $3 \mathrm{a}$ yield decreased to $62 \%$.

It is known that (het)aryl-containing iodides should often enter into cross-coupling reactions easier. ${ }^{57}$ Thus, we carried out a series of reactions of 4-iodo-5-trifluoromethyl-antipyrines 5a with phenylboronic acid to give 4-phenyl-5-trifluoromethylantipyrine 3a using similar catalytic systems as those used in the reactions of bromo-substituted analog $\mathbf{4 a}$. The performed experiments showed, regardless of the use of various phosphonium ligands and Pd catalysts, the main process in these reactions at high temperature was the deiodation of 4-iodoantipyrine 5a into antipyrine 1a. The yield of the desired product 3a was reduced significantly (entries $1-4$, Table S3†). The replacement of base $\mathrm{K}_{2} \mathrm{CO}_{3}$ by $\mathrm{Cs}_{2} \mathrm{CO}_{3}$ did not have influence on the reaction (entry 5, Table S3 $\uparrow$ ). However, the reaction under the optimal conditions for transformations of bromoantipyrine 4a (1.2 equiv. of phenylboronic acid in the presence of 2.5 equiv. of base $\mathrm{K}_{2} \mathrm{CO}_{3}, 0.02$ equiv. of $\operatorname{Pd}_{2}(\mathrm{dba})_{3}$ and 0.04 equiv. of XPhos), carried out at room temperature, allowed us to realize $100 \%$ conversion of the initial iodo-antipyrine $\mathbf{5 a}$ into 4-phenyl-5-trifluoromethyl-antipyrine 3a (entry 6, Table S3 $\dagger$ ). The yield of compound 3a was $89 \%$ after purification. Therefore, these conditions may be considered as the most effective, although the reaction at room temperature proceeded for longer time but with almost quantitative yield. The comparative reaction with 0.05 equiv. of $\mathrm{Pd}\left(\mathrm{PPh}_{3}\right)_{4}$ was found to be ineffective (entry 7 , Table S3†).

Using the selected optimal conditions, a series of 4-phenyl-5polyfluoroalkyl-antipyrines $\mathbf{3 a}, \mathbf{h}, \mathbf{j}$, $\mathbf{l}$ was synthesized (Scheme 3). The yields of heterocycles $\mathbf{3 a}, \mathbf{h}$ obtained from iodoantipyrines $\mathbf{5 a}, \mathbf{b}$ were slightly higher than in the case of bromo-substituted analogs $\mathbf{4 a}, \mathbf{b}$, because the reaction at room temperature allowed dehalogention of the initial compounds $\mathbf{5 a}, \mathbf{b}$ to be avoided. Note that bromo-antipyrine $4 \mathbf{a}$ practically did not react at room temperature.

In addition, the optimal conditions were successfully applied to the reactions of halogen antipyrines $\mathbf{4 a - d}$ and $\mathbf{5 a}$, b with [4-(methylthio)phenyl]boronic acid to generate new 4-[4(methylthio)phenyl]-5-polyfluoroalkyl-antipyrines 3g, i, $\quad \mathbf{k}$ (Scheme 3).

The structure of the obtained 4-aryl-5-polyfluoroalkylantipyrines $\mathbf{3 a}, \mathbf{d}-\mathbf{f}, \mathbf{g}-\mathbf{l}$ was confirmed by the elemental analysis, IR and NMR spectroscopy. The IR spectra of compounds 3a, $\mathbf{d - f}, \mathbf{g}-\mathbf{l}$ had a similar character. For example, the absorption
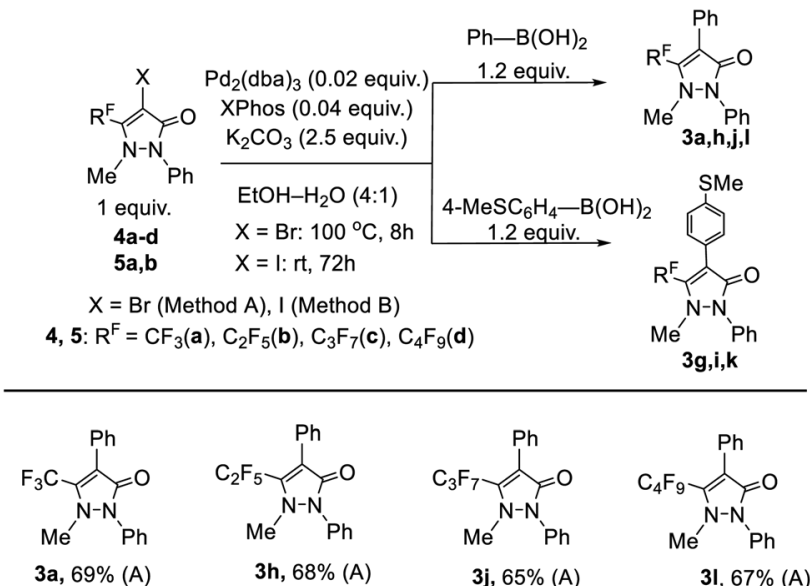

3a, 69\% (A)

$89 \%$ (B)
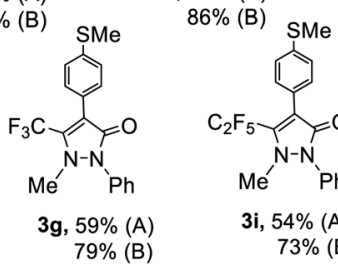

3j, $65 \%$ (A)
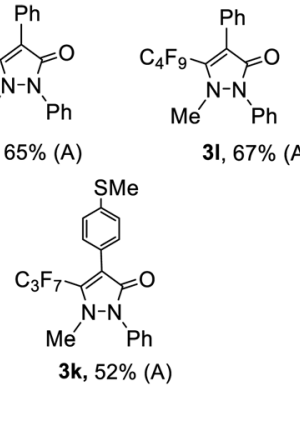

Scheme 3 Synthesis of 4-aryl-5-polyfluoroalkyl-antipyrines 3a, g-l.

bands of the carbonyl groups of compounds $\mathbf{3 a}, \mathbf{d}-\mathbf{f}, \mathbf{g}-\mathbf{l}$ were observed at $\nu_{\mathrm{CO}} 1660-1680 \mathrm{~cm}^{-1}$. The ${ }^{1} \mathrm{H}$ NMR spectra of antipyrines $\mathbf{3 a}, \mathbf{d}-\mathbf{f}, \mathbf{g}-\mathbf{l}$ were characterized with the presence of methyl and additional aryl protons.

We also performed the X-ray diffraction analysis (XRD) for the compound $3 \mathbf{e}$ to determine its exact structure (Fig. 3).

Then, we studied the Sonogashira cross-coupling reactions of 4-halogen-antipyrines $\mathbf{4 a - d , ~} \mathbf{5 a}, \mathbf{b}$ with phenylacetylene. We also began the investigation of these reactions with the search for the optimal conditions, varying the phosphonium ligands and palladium catalyst.

In contrast to the Suzuki reactions, the Sonogashira crosscoupling reactions are commonly carried out in acetonitrile in the presence of copper(I) iodide as co-catalyst and DIPEA as a base. Therefore, we performed a series of the reactions of 1 equiv. of 4-bromo-5-trifluoromethyl-antipyrine $4 \mathrm{a}$ with 1.5 equiv. of phenylacetylene in the presence of 2.0 equiv. of DIPEA and 0.1 equiv. of co-catalyst $\mathrm{CuI}$, using various pallidum catalyst and phosphine ligands in acetonitrile at $80^{\circ} \mathrm{C}$ in the closed vials

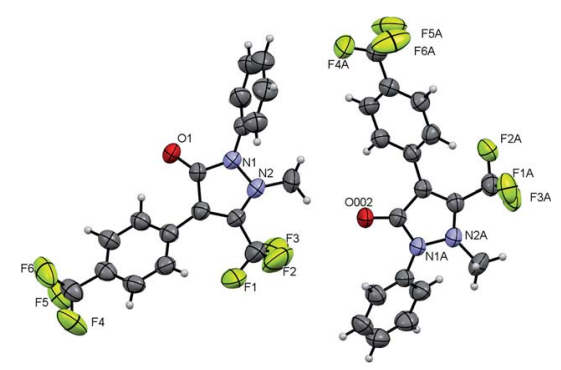

Fig. 3 The structure of 1-methyl-2-phenyl-5-(trifluoromethyl)-4-[4(trifluoromethyl)phenyl]-1,2-dihydro-3H-pyrazol-3-one 3e according to XRD (CCDC 2110385†). 
under argon for $12 \mathrm{~h}$ (entries 1, 3-5, Table S4 $\dagger$ ). However, these conditions did not lead to satisfactory results owing to incomplete conversion of the starting bromo-antipyrine $\mathbf{4 a}$ and the formation of a large number of by-products (mainly phenylacetylene crosslinking product - 1,4-diphenyl-1,3-butadiyne). According to GLC-mass spectrometry data, the content of the targeted 1-methyl-2-phenyl-4-(phenylethynyl)-5-(trifluoromethyl)-1,2-dihydro-3 $H$-pyrazol-3-one $\mathbf{6 a}$ in the reactions mixtures was recorded in the range of 8 to $30 \%$. The reaction with 0.05 equiv. of $\mathrm{Pd}\left(\mathrm{PPh}_{3}\right)_{4}$ (entry 2) or with 0.02 equiv. of $\mathrm{Pd}_{2}(\mathrm{dba})_{3}$ and 0.04 equiv. of XPhos (entry 6) at $100{ }^{\circ} \mathrm{C}$ for $6 \mathrm{~h}$ resulted in a slight increase of product $6 \mathbf{a}$ to 35 and $36 \%$, respectively. The yield of the targeted heterocycle $6 \mathbf{a}$ was $26 \%$ after purification (entry 6, Table S4 $\dagger$ ).

Further, we used 4-iodo-5-trifluoromethyl-antipyrine $\mathbf{5 a}$ as the initial reagent in the reaction with phenylacetylene (Table $\mathrm{S} 5 \dagger$ ). To perform a series of experiments, the already proven catalytic system $\operatorname{Pd}_{2}(\mathrm{dba})_{3}$-XPhos was chosen. The reaction of antipyrine 5a with 1.5 equiv. of phenylacetylene was carried out in the closed vials under argon in the presence of 0.02 equiv. of $\mathrm{Pd}_{2}(\mathrm{dba})_{3}, 0.04$ equiv. of XPhos, 2.0 equiv. of DIPEA and 0.1 equiv. of $\mathrm{CuI}$ in different solvents at heating or at room temperature (Table $\mathrm{S} 5 \dagger$ ).

The reaction in toluene at $100{ }^{\circ} \mathrm{C}$ was found to result in a mixture of by-products, and the content of the targeted 4(phenylethynyl)-5-(trifluoromethyl)-antipyrine 6 a was only $2 \%$ (entry 1, Table S5†). Using 1,4-dioxane (entry 2) or acetonitrile (entry 3 ) at the same temperature led to significant deiodation of the initial iodo-antipyrine 5a, but the content of the desired heterocycle $6 \mathbf{a}$ was slightly higher $(25 \%)$ in acetonitrile than in 1,4-dioxane $(13 \%)$. At a lower reaction temperature $\left(50{ }^{\circ} \mathrm{C}\right)$ in acetonitrile the content of targeted compound $6 \mathbf{6}$ increased up to $35 \%$ (entry 4 , Table $55 \dagger$ ).

The most effective conditions for the Sonogashira reaction of iodo-antipyrine 5a with phenylacetylene was found to hold the reaction mass in acetonitrile at room temperature for $72 \mathrm{~h}$ (entry 6, Table S5 $\dagger$ ). Here, the full conversion of the initial iodoantipyrine 5a occurred but this transformation was also accompanied by a side process: self-condensation of phenylacetylene to form 1,4-diphenyl-1,3-butadiyne. The content of the desired product $6 \mathbf{a}$ in the reaction mixture was $75 \%$ and the yield after purification was $60 \%$. The found optimal conditions were used to generate pentafluoroethyl substituted analog $\mathbf{6 b}$ (Scheme 4).

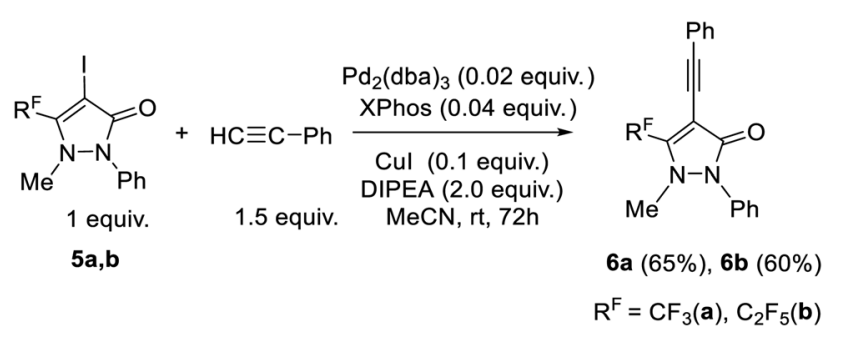

Scheme 4 Synthesis of 4-(phenylethynyl)-5-(polyfluoroalkyl)-antipyrines $6 a, b$.
The structure of 4-(phenylethynyl)-5-(polyfluoroalkyl)antipyrines 6a, b was confirmed by the elemental analysis, IR and NMR spectroscopy. The existence of triple bond was affirmed by the presence in the ${ }^{13} \mathrm{C}$ NMR spectra of the chemical shifts at $\delta$ 76.4-76.6 and 97.8-98.0 ppm, which are typical of two sp-hybridized carbon atoms. ${ }^{45,58}$

\section{Biological testing}

Iodoantipyrine has been known to be applied in the medicinal practice to treat and prevent tick-borne encephalitis, ${ }^{\mathbf{5 9 , 6 0}}$ influenza and infections caused by nonpoliomyelitis enteroviruses of Coxsackie and ECHO groups. ${ }^{60}$ We evaluated an antiviral activity of the synthesized polyfluoroalkyl-containing iodoantipyrines 5a, b, and aryl-3a, $\mathbf{g}$ and phenylethynyl-substituted 6a antipyrines against the influenza virus A/Puerto Rico/8/34 (H1N1) on MDCK cell line (Table 1) using ribavirin as a reference drug according the published procedure. ${ }^{61}$

Studying the cytotoxicity of compounds on the MDCK cell line, it was found that compounds $5 \mathbf{a}, \mathbf{6 a}$ have lower cytotoxicity $\left(\mathrm{CC}_{50}>815 \mu \mathrm{M}\right)$ compared to the derivatives $\mathbf{5 b}, \mathbf{3 a}$ and $\mathbf{3 g}$. The elongation of polyfluoroalkyl chain in iodo-antipyrines $\mathbf{5 a}$, b led to the increase of cytotoxicity $\left(5 \mathbf{a ~} \mathrm{CC}_{50}>815 \mu \mathrm{M} v s .5 \mathbf{b} \mathrm{CC}_{50} 378\right.$ $\mu \mathrm{M})$. The introduction of phenyl substituent resulted in the increased cytotoxic properties of compound $3 \mathrm{a}\left(\mathrm{CC}_{50} 789 \mu \mathrm{M}\right)$ in comparison with the methylthiophenyl analog $3 \mathrm{~g}\left(\mathrm{CC}_{50} 263\right.$ $\mu \mathrm{M})$. Phenylethyl derivative $6 \mathbf{a}\left(\mathrm{CC}_{50}>877 \mu \mathrm{M}\right)$ showed the lowest cytotoxicity.

The virus-inhibiting activity of iodo-antipyrines $\mathbf{5 a}, \mathbf{b}$ and phenyl-antipyrines 3a was low $\left(\mathrm{IC}_{50}>314-177 \mu \mathrm{M}\right)$, therefore their selectivity index did not exceed 5 . The activity of methylthiophenyl-antipyrine $3 \mathrm{~g}$ increased up to $\mathrm{IC}_{50} 91 \mu \mathrm{M}$, but it has a low $\mathrm{SI}=3$ owing to the raised cytotoxicity. The best ratio of cytotoxic and inhibitory properties was shown by phenylethynyl antipyrine $6 \mathbf{a}$ with $\mathrm{SI}=15$.

The evaluation of antiviral activity of $\mathrm{CF}_{3}$-iodo-antipyrine $\mathbf{5 a}$ was carried out in vitro against the vaccine virus (VV, strain Copenhagen), herpes simplex virus type 1 (HSV-1, strain VR-3) and bovine diarrhea virus (BDV) (strain VC-1), a surrogate of the hepatitis $\mathrm{C}$ virus on the cells of the calf coronary vessels (CCV). It was found that heterocycle 5a was inactive against

Table 1 Antiviral activity of compounds 5a, b, 3a, g, 6a against influenza virus A/Puerto Rico/8/34 (H1N1) on the MDCK cell line ${ }^{a}$

\begin{tabular}{llllr}
\hline No. & Compound & $\mathrm{CC}_{50}, \mu \mathrm{M}$ & $\mathrm{IC}_{50}, \mu \mathrm{M}$ & $\mathrm{SI}$ \\
\hline 1 & $\mathbf{5 a}$ & $>815$ & $177 \pm 21$ & 5 \\
2 & $\mathbf{5 b}$ & $378 \pm 26$ & $205 \pm 19$ & 2 \\
3 & $\mathbf{3 a}$ & $789 \pm 57$ & $>314$ & 3 \\
4 & $\mathbf{3 g}$ & $263 \pm 19$ & $>91$ & 3 \\
5 & $\mathbf{6 a}$ & $>877$ & $58 \pm 8$ & 15 \\
6 & Ribavirin & $>2130$ & $36 \pm 5$ & 59
\end{tabular}

${ }^{a} \mathrm{CC}_{50}-50 \%$ cytotoxic concentration, the concentration resulting in death of $50 \%$ of cells in culture; $\mathrm{IC}_{50}-50 \%$ inhibiting concentration, the concentration resulting in a $50 \%$ decrease of virus production as compared to the control; SI - selectivity index $\left(\mathrm{CC}_{50} / \mathrm{IC}_{50}\right)$. 
Table 2 Cytotoxic and antiviral activity of compound 5a on the Vero cells against VV, HSV-1, and on the CCV cells against BDV ${ }^{a}$

\begin{tabular}{|c|c|c|c|c|c|c|c|}
\hline $\mathrm{CC}_{50}, \mu \mathrm{M}$ & $\mathrm{IC}_{50}, \mu \mathrm{M}$ & & $\mathrm{IC}_{50}, \mu \mathrm{M}$ & & $\mathrm{CC}_{50}, \mu \mathrm{M}$ & $\mathrm{IC}_{50}, \mu \mathrm{M}$ & \\
\hline Vero & $\mathrm{VV}$ & $\mathrm{SI}_{\mathrm{BOB}}$ & HSV-1 & $\mathrm{SI}_{\mathrm{HSV}-1}$ & $\mathrm{CCV}$ & BDV & $\mathrm{SI}_{\mathrm{VDC}}$ \\
\hline
\end{tabular}

${ }^{a} \mathrm{CC}_{50}-50 \%$ cytotoxic concentration, the concentration resulting in death of $50 \%$ of cells in culture; $\mathrm{IC}_{50}-50 \%$ inhibiting concentration, the concentration resulting in a $50 \%$ decrease of the virus production as compared to control; SI - selectivity index.

HSV-1, but it showed a weak activity against strains of SVV and VDC with SI 2.9 and 6.4, respectively (Table 2).

\section{Conclusions}

In summary, we found a weak reactivity of $\mathrm{CF}_{3}$-antipyrine in $\mathrm{Pd}$ catalyzed reactions of the direct arylation owing to a decrease in the nucleophilicity of its $\mathrm{C} 4$ site compared to antipyrine. For the purpose of modification of polyfluoroalkyl-substituted antipyrines at the $\mathrm{C} 4$ center, the Suzuki and Sonogashira reactions via the preliminary synthesis of 4-bromo- and 4-iodo-derivatives were found to be effective. Using $\mathrm{Pd}_{2}(\mathrm{dba})_{3}$ as catalyst and $\mathrm{XPhos}$ as phosphine ligand were found to be the optimal conditions for the preparation of 4-aryl- and 4-phenylethynyl-3$\mathrm{R}^{\mathrm{F}}$-antipyrines. In addition, the application of iodo- $\mathrm{R}^{\mathrm{F}}$-antipyrines as the initial reagents was more advantageous compared to bromo-containing analogs, since they were easily and more efficiently transformed into the target products at room temperatures. The synthesis under such mild conditions allowed us to avoid dehalogenation of the starting halogen- $\mathrm{R}^{\mathrm{F}}$ antipyrines. Note that this process was the main side reaction in the studied transformations, which reduces significantly the yield of the target products.

The investigation of antiviral activity of the new derivatives of polyfluoroalkyl-containing antipyrines showed a moderate activity of 4-phenylethynyl-5- $\mathrm{CF}_{3}$-antipyrine against the influenza virus A/Puerto Rico/8/34 (H1N1) and a weak activity of iodo-5- $\mathrm{CF}_{3}$-antipyrines against vaccine virus (strain Copenhagen) and bovine diarrhea virus (strain VC-1), a surrogate of the hepatitis $\mathrm{C}$ virus.

\section{Author contributions}

E. V. Shchegolkov: conceptualization, methodology, validation, investigation, data curation, writing - original draft, writing review \& editing, visualization. Y. V. Burgart: conceptualization, methodology, validation, writing - original draft, writing review \& editing, visualization. D. A. Matsneva: investigation, formal analysis. S. S. Borisevich: formal analysis, visualization. R. A. Kadyrova: investigation, formal analysis. I. R. Orshanskaya: investigation, formal analysis. V. V. Zarubaev: data curation, validation, resources, writing - original draft. V. I. Saloutin: conceptualization, resources, writing - review \& editing, funding acquisition.

\section{Conflicts of interest}

The authors declare that they have no known competing financial interests or personal relationships that could have appeared to influence the work reported in this paper.

\section{Acknowledgements}

This work was supported by the Russian Science Foundation (grant no. 21-13-00390). Analytical studies were carried out using equipment of the Center for Joint Use "Spectroscopy and Analysis of Organic Compounds" at the Postovsky Institute of Organic Synthesis of UB RAS. We are grateful to Natalia Yu. Pomortseva for her assistance in preparing the manuscript.

\section{Notes and references}

1 J. Akhtar, A. A. Khan, Z. Ali, R. Haider and M. Shahar Yar, Eur. J. Med. Chem., 2017, 125, 143-189.

2 D. Havrylyuk, O. Roman and R. Lesyk, Eur. J. Med. Chem., 2016, 113, 145-166.

3 M. F. Khan, M. M. Alam, G. Verma, W. Akhtar, M. Akhter and M. Shaquiquzzaman, Eur. J. Med. Chem., 2016, 120, 170-201.

4 K. Karrouchi, S. Radi, Y. Ramli, J. Taoufik, Y. Mabkhot, F. Alaizari and M. Ansar, Molecules, 2018, 23, 134.

5 K. Kaur, V. Kumar and G. K. Gupta, J. Fluorine Chem., 2015, 178, 306-326.

6 Ş. G. Küçükgüzel and S. Şenkardeş, Eur. J. Med. Chem., 2015, 97, 786-815.

7 R. S. Keri, K. Chand, T. Ramakrishnappa and B. M. Nagaraja, Arch. Pharm., 2015, 348, 299-314.

8 M. Aghazadeh Tabrizi, P. G. Baraldi, P. A. Borea and K. Varani, Chem. Rev., 2016, 116, 519-560.

9 L. Pizzuti, A. G. Barschak, F. M. Stefanello, M. D. Farias, C. Lencina, M. Roesch-Ely, W. Cunico, S. Moura and C. M. P. Pereira, Curr. Org. Chem., 2014, 18, 115-126.

10 D. Dias, B. Pacheco, W. Cunico, L. Pizzuti and C. Pereira, Mini-Rev. Med. Chem., 2015, 14, 1078-1092.

11 Z. Zhao, X. Dai, C. Li, X. Wang, J. Tian, Y. Feng, J. Xie, C. Ma, Z. Nie, P. Fan, M. Qian, X. He, S. Wu, Y. Zhang and X. Zheng, Eur. J. Med. Chem., 2020, 186, 111893.

12 P. Chauhan, S. Mahajan and D. Enders, Chem. Commun., 2015, 51, 12890-12907.

13 J. Sahoo, C. R. Sahoo, P. K. Nandini Sarangi, S. K. Prusty, R. N. Padhy and S. K. Paidesetty, Eur. J. Med. Chem., 2020, 186, 111911. 
14 L. Yet, Five-Membered Ring Systems: With More than One N Atom, in Progress in Heterocyclic Chemistry, 2020, Ch. 5.4, pp. 325-361.

15 P. Gunasekaran, S. Perumal, P. Yogeeswari and D. Sriram, Eur. J. Med. Chem., 2011, 46, 4530-4536.

16 C. Soares de Melo, V. Singh, A. Myrick, S. B. Simelane, D. Taylor, C. Brunschwig, N. Lawrence, D. Schnappinger, C. A. Engelhart, A. Kumar, T. Parish, Q. Su, T. G. Myers, H. I. M. Boshoff, C. E. Barry, F. A. Sirgel, P. D. van Helden, K. I. Buchanan, T. Bayliss, S. R. Green, P. C. Ray, P. G. Wyatt, G. S. Basarab, C. J. Eyermann, K. Chibale and S. R. Ghorpade, J. Med. Chem., 2021, 64, 719-740.

17 T. Pillaiyar, M. Manickam, V. Namasivayam, Y. Hayashi and S.-H. Jung, J. Med. Chem., 2016, 59, 6595-6628.

18 Y. Mostinski, G. J. J. E. Heynen, M. P. López-Alberca, J. Paul, S. Miksche, S. Radetzki, D. Schaller, E. Shanina, C. Seyffarth, Y. Kolomeets, N. Ziebart, J. de Schryver, S. Oestreich, M. Neuenschwander, Y. Roske, U. Heinemann, C. Rademacher, A. Volkamer, J. P. von Kries, W. Birchmeier and M. Nazaré, J. Med. Chem., 2020, 63, 14780-14804.

19 G. Saidachary, K. Veera Prasad, D. Divya, A. Singh, U. Ramesh, B. Sridhar and B. China Raju, Eur. J. Med. Chem., 2014, 76, 460-469.

20 N. S. Gavande, P. VanderVere-Carozza, A. K. Mishra, T. L. Vernon, K. S. Pawelczak and J. J. Turchi, J. Med. Chem., 2017, 60, 8055-8070.

21 A. L. Smith, K. L. Andrews, H. Beckmann, S. F. Bellon, P. J. Beltran, S. Booker, H. Chen, Y.-A. Chung, N. D. D'Angelo, J. Dao, K. R. Dellamaggiore, P. Jaeckel, R. Kendall, K. Labitzke, A. M. Long, S. Materna-Reichelt, P. Mitchell, M. H. Norman, D. Powers, M. Rose, P. L. Shaffer, M. M. Wu and J. R. Lipford, J. Med. Chem., 2015, 58, 1426-1441.

22 N. Uramaru, H. Shigematsu, A. Toda, R. Eyanagi, S. Kitamura and S. Ohta, J. Med. Chem., 2010, 53, 8727-8733.

23 O. Corminboeuf and X. Leroy, J. Med. Chem., 2015, 58, 537559.

24 P. M. P. Santos, A. M. M. Antunes, J. Noronha, E. Fernandes and A. J. S. C. Vieira, Eur. J. Med. Chem., 2010, 45, 2258-2264.

25 S. Yousuf, K. M. Khan, U. Salar, S. Chigurupati, M. T. Muhammad, A. Wadood, M. Aldubayan, V. Vijayan, M. Riaz and S. Perveen, Eur. J. Med. Chem., 2018, 159, 47-58.

26 D. Zimmermann, Y. L. Janin, L. Brehm, H. Bräuner-Osborne, B. Ebert, T. N. Johansen, U. Madsen and P. KrogsgaardLarsen, Eur. J. Med. Chem., 1999, 34, 967-976.

27 Y. Zhang, K. T. Zhao, S. G. Fox, J. Kim, D. R. Kirsch, R. J. Ferrante, R. I. Morimoto and R. B. Silverman, J. Med. Chem., 2015, 58, 5942-5949.

28 W. R. Dolbier, J. Fluorine Chem., 2005, 126, 157-163.

29 P. K. Mykhailiuk, Chem. Rev., 2021, 121, 1670-1715.

30 J. C. Sloop, C. Holder and M. Henary, Eur. J. Org. Chem., 2015, 2015, 3405-3422.

31 S. Purser, P. R. Moore, S. Swallow and V. Gouverneur, Chem. Soc. Rev., 2008, 37, 320-330.

32 E. Prchalová, O. Štěpánek, S. Smrček and M. Kotora, Future Med. Chem., 2014, 6, 1201-1229.
33 J. Han, L. Kiss, H. Mei, A. M. Remete, M. Ponikvar-Svet, D. M. Sedgwick, R. Roman, S. Fustero, H. Moriwaki and V. A. Soloshonok, Chem. Rev., 2021, 121, 4678-4742.

34 T. D. Penning, J. J. Talley, S. R. Bertenshaw, J. S. Carter, P. W. Collins, S. Docter, M. J. Graneto, L. F. Lee, J. W. Malecha, J. M. Miyashiro, R. S. Rogers, D. J. Rogier, S. S. Yu, G. D. Anderson, E. G. Burton, J. N. Cogburn, S. A. Gregory, C. M. Koboldt, W. E. Perkins, K. Seibert, A. W. Veenhuizen, Y. Y. Zhang and P. C. Isakson, J. Med. Chem., 1997, 40, 1347-1365.

35 S. R. Cox, S. P. Lesman, J. F. Boucher, M. J. Krautmann, B. D. Hummel, M. Savides, S. Marsh, A. Fielder and M. R. Stegemann, J. Vet. Pharmacol. Ther., 2010, 33, 461-470. 36 M. L. Quan, P. Y. S. Lam, Q. Han, D. J. P. Pinto, M. Y. He, R. Li, C. D. Ellis, C. G. Clark, C. A. Teleha, J.-H. Sun, R. S. Alexander, S. Bai, J. M. Luettgen, R. M. Knabb, P. C. Wong and R. R. Wexler, J. Med. Chem., 2005, 48, 1729-1744.

37 N. A. Nemytova, E. V. Shchegol'kov, Y. V. Burgart, P. A. Slepukhin, S. S. Borisevich, S. L. Khursan and V. I. Saloutin, J. Fluorine Chem., 2018, 206, 72-81.

38 N. Agafonova, E. Shchegolkov, Y. Burgart, V. Saloutin, A. Trefilova, G. Triandafilova, S. Solodnikov, V. Maslova, S. Borisevich, O. Krasnykh and S. Khursan, Med. Chem., 2019, 15, 521-536.

39 A. Suzuki, Angew. Chem., Int. Ed., 2011, 50, 6722-6737.

40 C. C. C. Johansson Seechurn, M. O. Kitching, T. J. Colacot and V. Snieckus, Angew. Chem., Int. Ed., 2012, 51, 5062-5085.

41 K. C. Nicolaou, P. G. Bulger and D. Sarlah, Angew. Chem., Int. Ed., 2005, 44, 4442-4489.

42 D. Wang and S. Gao, Org. Chem. Front., 2014, 1, 556-566.

43 J. P. Chupp, J. Heterocycl. Chem., 1994, 31, 1377-1380.

44 A. E. Ivanova, Y. V Burgart and V. I. Saloutin, Russ. J. Org. Chem., 2018, 54, 1265-1267.

45 V. M. Muzalevskiy and V. G. Nenajdenko, Org. Biomol. Chem., 2018, 16, 7935-7946.

46 H. Gong, Y. Yang, Z. Wang and C. Kuang, Beilstein J. Org. Chem., 2013, 9, 2033-2039.

47 A. Sasmal, J. K. Bera, H. Doucet and J.-F. Soulé, Tetrahedron Lett., 2020, 61, 151798.

48 W. Ma, H. Dong, D. Wang and L. Ackermann, Adv. Synth. Catal., 2017, 359, 966-973.

49 S. A. Yakukhnov, E. O. Pentsak, K. I. Galkin, R. M. Mironenko, V. A. Drozdov, V. A. Likholobov and V. P. Ananikov, ChemCatChem, 2018, 10, 1869-1873.

50 X. Wang, X. Li, Y. Zhang and L. Xia, Org. Biomol. Chem., 2018, 16, 2860-2864.

51 S. Mao, X. Shi, J.-F. Soulé and H. Doucet, Adv. Synth. Catal., 2018, 360, 3306-3317.

52 P. Arockiam, V. Poirier, C. Fischmeister, C. Bruneau and P. H. Dixneuf, Green Chem., 2009, 11, 1871.

53 J. J. Dong, J. Roger, C. Verrier, T. Martin, R. Le Goff, C. Hoarau and H. Doucet, Green Chem., 2010, 12, 2053.

54 A. Hfaiedh, K. Yuan, H. Ben Ammar, B. Ben Hassine, J.-F. Soulé and H. Doucet, ChemSusChem, 2015, 8, 17941804.

55 J. I. Martínez-Araya, J. Math. Chem., 2015, 53, 451-465. 
56 J. Oláh, C. Van Alsenoy and A. B. Sannigrahi, J. Phys. Chem. A, 2002, 106, 3885-3890.

57 In Name Reactions for Homologations, Part I, ed. J. J. Li, Wiley \& Sons, Inc., 2009, pp. 1-333.

58 E. Pretsch, P. Bulmann and C. Affolter, Structure determination of organic compounds, Springer-Verlag, Berlin, Heidelberg, 2000.

59 V. E. Iavorovskaia, A. S. Saratikov, I. V. Fedorov, A. N. Evstropov, R. G. Solianik, G. V. Anosova,
E. V. Lepekhin and A. V. Portniagina, Exp. Clin. Pharmacol., 1998, 61, 51-53.

60 A. S. Saratikov and V. E. Yavorovskaya, Pharm. Chem. J., 1997, 31, 333-334.

61 N. A. Elkina, Y. V. Burgart, E. V. Shchegolkov, O. P. Krasnykh, V. V. Maslova, G. A. Triandafilova, S. S. Solodnikov, A. A. Muryleva, M. A. Misiurina, A. V. Slita, V. V. Zarubaev and V. I. Saloutin, J. Fluorine Chem., 2020, 240, 109648. 